\title{
Production of value added products from separately collected urine
}

\author{
J. Behrendt ${ }^{*}$, E. Arevalo ${ }^{*}$, H. Gulyas ${ }^{*}$, J. Niederste-Hollenberg ${ }^{*}$, A. Niemiec ${ }^{* *}$, J. Zhou ${ }^{*}$, R. Otterpohl ${ }^{*}$
}

\begin{abstract}
*Institute of Wastewater Management, Technical University Hamburg-Harburg, Eissendorfer Str. 42, 21073 Hamburg, Germany (j.behrendt@tuhh.de)

**Warsaw University of Technology, Institute of Environmental Engineering Systems, Nowowiejska 20, PL-00653

Warsaw, Poland
\end{abstract}

\begin{abstract}
For many reasons it is advantageous to collect urine separately Otterpohl,R. (2001) and also collection system, so called "no-mix-toilets" exist Braun,U. (2001); Galler,L. (2001). Therefore, this work deals with some methods to make use of this urine to produce value added products: IBDU and ammonia water. It could be shown that urea can be converted to IBDU only after concentrating urine. With air stripping and absorption ammonificated urine can be treated very effectively and a solution of $10 \% \mathrm{w} / \mathrm{w}$ of ammonia can be obtained.
\end{abstract}

Keywords

source control, sustainable technology, fertiliser

\section{INTRODUCTION}

The yearly consumption of water per person is about $50 \mathrm{~m}^{3}$, while only $0.5 \mathrm{~m}^{3}$ of urine and faeces are produced. Human excreta contain the main part of nutrients and hazardous substances. If the urine and faeces are collected separately, a production of value added products seems possible. As a positive sideeffect the spreading of pathogens and water pollution are prevented. Separation technologies for different flows of domestic wastewater are developed, but there is a lack of techniques for the treatment of urine ("yellow water", containing around $85 \%$ of nitrogen), faeces ("brown water") and grey water (can be purified for reuse). In figure 1, some options for the treatment of separately collected urine are illustrated (from Esrey,St.A. et al. (1998) modified). The proposed option "soak pit" has to be rejected to prevent groundwater contamination. Agricultural use is put into practise in some Swedish projects with great success Hellström,D. and Johansson,E. (1995) and Jönsson,H. et al. (1999). This is a good option for rural areas. In urban areas with a high population density the storage and transportation of the separately collected urine could be problematic. Therefore, concentration techniques should be used. There are some experiences for concentrating urine nutrients that have shown their potenial to concentrate the urine with small nutrient losses: dewatering by evaporation with and without nitrification and freeze concentration Gulyas,H. (2000). Another possibility to make use of the nutrients in urine is the separation of the value added components from the aqueous matrix. One approach is chemical reaction that leeds to easy separable solid substance. Ammonia and phosphate react with magnesia under alkaline conditions to struvite that can be used as fertiliser in agriculture Strand,L. and Odén,L. (2000), Lind,B.-B. et al. (2000). In this case the addition of magnesium oxide is required. In this paper the production of Isobuthylaldehyde-di-urea IBDU from urine is discussed. Isobutyicaldehyde reacts with urea and forms the slow release fertiliser IBDU. Besides due to the high amount of nitrogen in urine, the stripping of ammonium has also been investigated. The aim was the production of ammonium-water with a concentration of at least $10 \%$. 


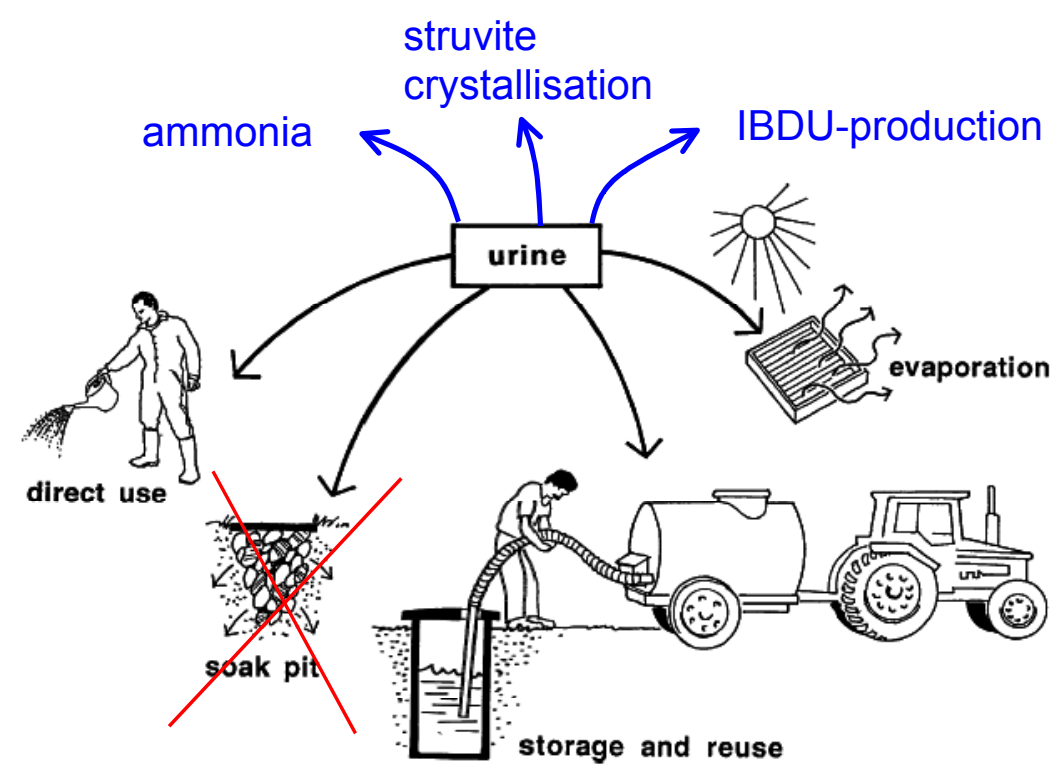

Figure 1. Proposed uses of urine (from Esrey,St.A. et al. (1998) modified)

\section{PRODUCTION OF IBDU}

In fresh urine about $80 \%$ the nitrogen is bound in urea. Urea reacts with isobutyric aldehyde (IBA) to IBDU, a slowly releasing nitrogen fertiliser that is used in high amounts all over the world. The chemical industry is producing IBDU from aquatic solutions of urea $\left(600-900 \mathrm{~kg} / \mathrm{m}^{3}\right)$ with IBA in a stoichiometric ratio at temperatures above $60{ }^{\circ} \mathrm{C}$ and $\mathrm{pH} 3$. The urea concentration in urine amounts to a maximum of 10 $\mathrm{kg} / \mathrm{m}^{3}$ only. By using concentrating techniques like freeze-concentration or evaporation a urea concentration of $100 \mathrm{~kg} / \mathrm{m}^{3}$ should be obtainable.

\section{Experimental set up}

Experiments were carried out with urea solution in tap water with $10 \mathrm{~g} / 1 \mathrm{NaCl}$ and with urine as batch experiments (closed vessel experiments). $10 \mathrm{ml}$ of the solutions were adjusted to the desired $\mathrm{pH}$ and temperature and poured into $20 \mathrm{ml}$ glass vials. The vials were closed with a septum. After injection the IBA into the vials, they were shaken for 5 minutes intensively and finally stored for $24 \mathrm{~h}$ for crystallisation and sedimentation. Ammonia (cuvette test Dr. Lange \#LCK303) and urea measured as ammonia after $24 \mathrm{~h}$ incubated with urease (Merck \#1.08489.0025) at pH.6 and $25^{\circ} \mathrm{C}$ were analysed in the supernatant. IBDU has been estimated by filtration of the precipitation products which have been dried and weighed after filtration.

\section{Results and discussion}

It was found that there is no influence of the temperature on the reaction under these conditions. The reaction and crystallisation time is very long ( 24 hours) and is not dependent on $\mathrm{pH}$ at $\mathrm{pH}<4$. The yields were up to $90 \%$, using pure aqueous urea solutions (see figure 2). Up to a stoichiometric dosage of IBA the conversion was nearly complete. Using urine, the IBDU-yield is only satisfactory when working with extreme excess of IBA because of low urea concentrations. When the urine was concentrated by evaporation prior to the reaction with IBA, yields of $>1$ were achieved, obviously due to simultaneous precipitation of other solids than IBDU, because the amount of formed IBDU has been estimated by filtration of the precipitation products. But at least over $75 \%$ of the nitrogen $(>50 \%$ TOC and only $25 \% \mathrm{P})$ in the urine has been converted to solids. With an optimisation of this process a higher P-removal can be achieved and a good quality fertiliser can be obtained. 


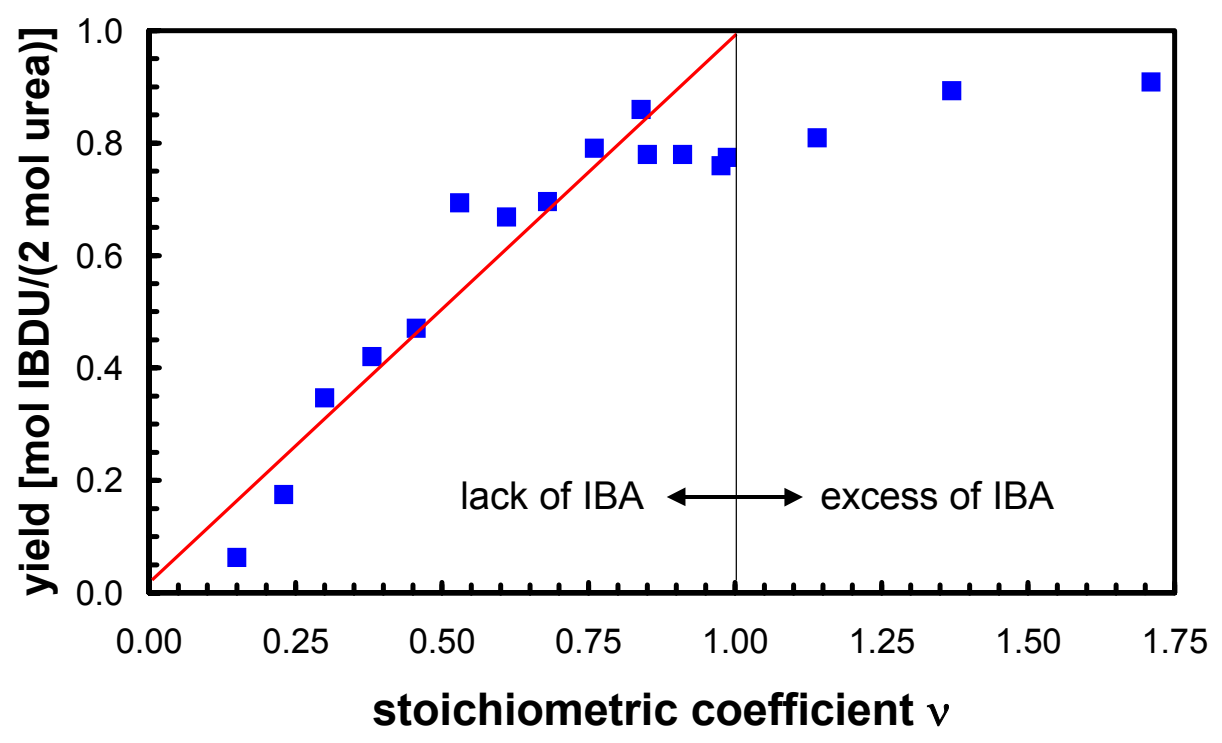

Figure 2. IBDU-yield in urea solution (100 g/l) dependent on the stoichiometric coefficient

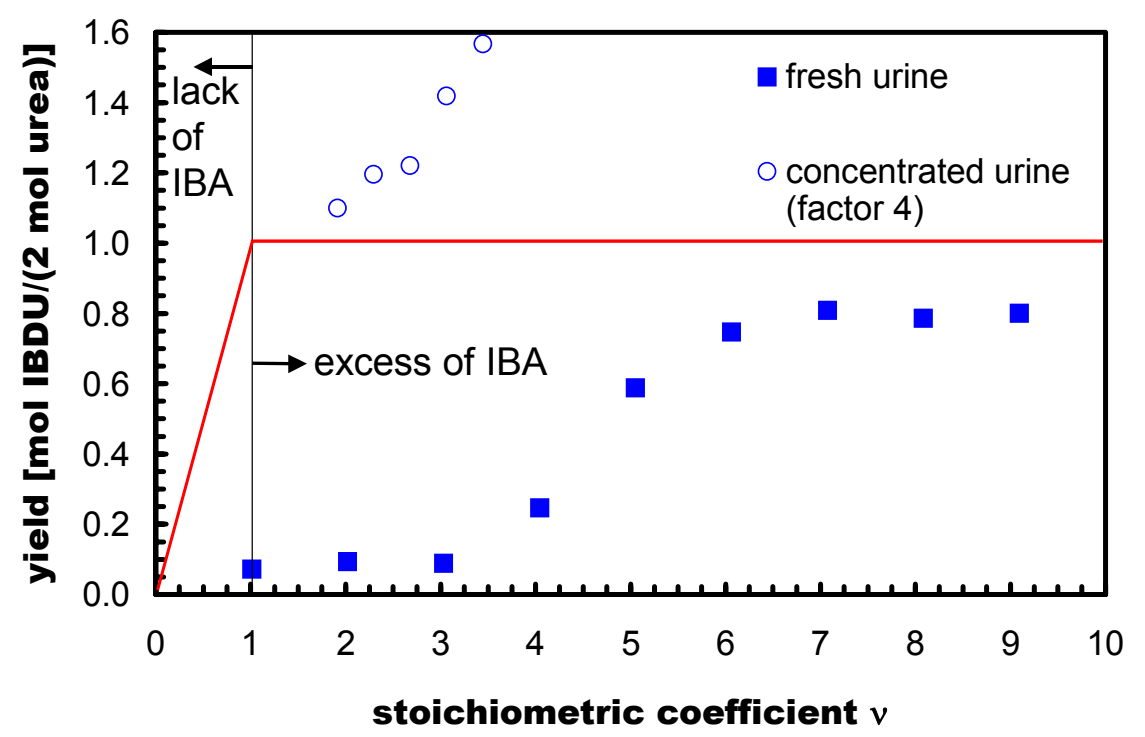

Figure 3. IBDU-yield in urine dependent on the stoichiometric coefficient

\section{PRODUCTION OF AMMONIA WATER}

After ammonification almost $90 \%$ of the nitrogen in urine consists of ammonium/ammonia, at high $\mathrm{pH}$ ( > 11) exclusively as ammonia. This gas can be separated from the liquid and concentrated in pure water. For ammonia water a market exists e.g. for nitrogen oxide removal from exhaust gases. In this work, the options of air-stripping were investigated.

\section{Experimental set up}

Experiments were carried out in a lab scale packed column (height $2 \mathrm{~m}, \varnothing 5 \mathrm{~cm})$ with plastic rings $(\varnothing 1 \mathrm{~cm}$, length $0.5 \mathrm{~cm}$ ) as packing material (s. figure 4). The liquid was circulated over the column and mixed in a thermostated stirred tank reactor (6 1 volume). Samples were taken manually from the stirred tank and analysed (cuvette test Dr. Lange \#LCK303 $\left(\mathrm{NH}_{4}-\mathrm{N}\right)$ and \# LCK238 $\left(\mathrm{N}_{\mathrm{t}}\right)$. Before the ammonia stripping process urine was treated with urease (Merck \#1.08489.0025) and stored until all urea was transformed in ammonia. Temperature and $\mathrm{pH}$ were adjusted in the stirred tank. 


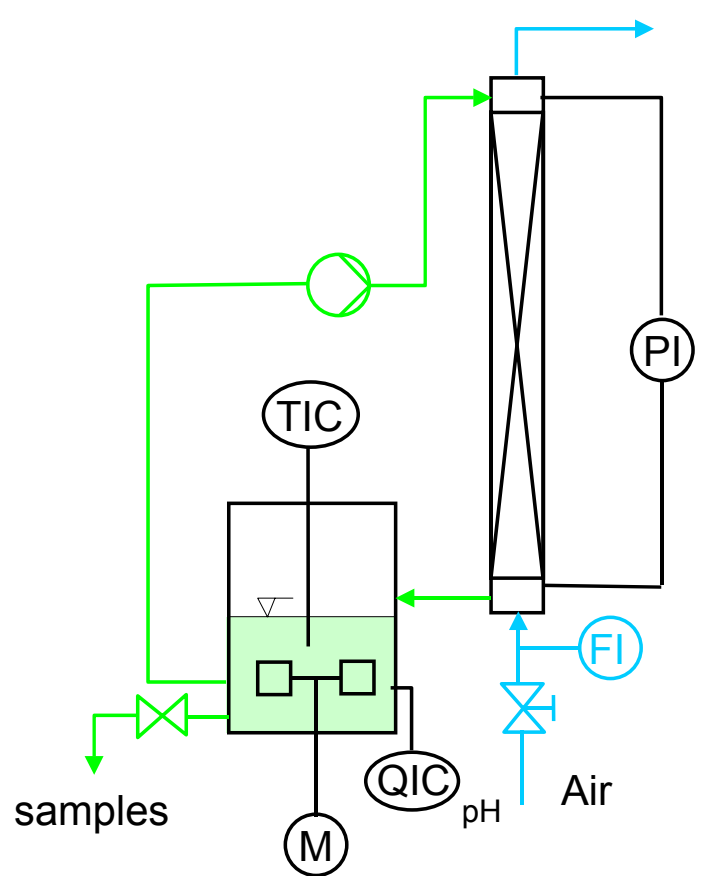

Figure 4. Experimental set up for the ammonia stripping experiments

\section{Results and discussion}

It could be shown that the residual concentration of ammonia/ammonium in model-water and urine were very low after stripping. Design parameters, especially the overall mass transfer coefficient $\left(K_{L} A\right)$ for ammonia in the system urine/air and for different temperatures were obtained from batch experiments. In figure 5 the results for batch experiments at different temperatures are presented. The experimental results could be simulated with a mathematical model to determine the $\mathrm{K}_{\mathrm{L}} \mathrm{A}$-values. The model consisted of 10 mass transfer units (MTU) that were connected in series. The equilibrium conditions were calculated from literature data and the geometrical and operating parameters of the laboratory scale experiments were used as input in the model.

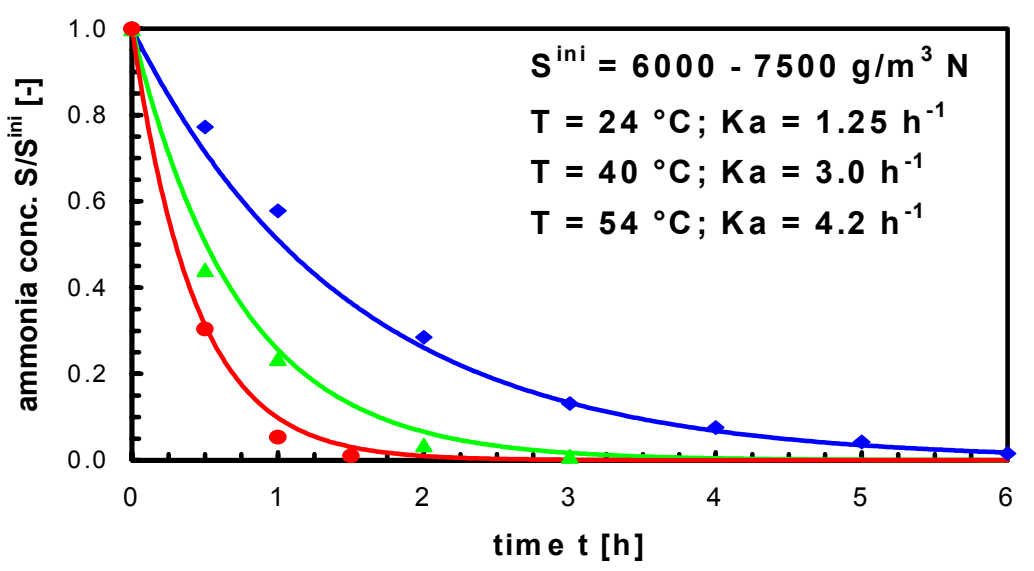

Figure 5. Experimental data and simulation results for a batch experiment on ammonia stripping in a packed bed

In figure 6 a possible process-setup for the production of ammonia-water is shown (the production of ammonium sulfate should be realised easier). The process consists of an air stripper for ammonia removal from urine and an absorber to remove the ammonia from the air producing the concentrated ammonia solution. The air will be recirculated from the absorber to the stripper to reduce ammonia losses. To obtain low ammonia concentration in the urine and high concentrations in the ammonia solution, the stripper is operated under low pressure and high temperature and the absorber under high pressure and low 
temperature. Based on the data for the $\mathrm{K}_{\mathrm{L}} \mathrm{A}$-values from batch experiment, a dimensioning of a unit for 10,000 population equivalents was implemented (1.2 $1 \mathrm{urine} /(\mathrm{PE} \mathrm{d}), 8 \mathrm{~h} / \mathrm{d}, 5 \mathrm{~d} /$ week operation of the plant). As the results in table 1 indicate, only very small units are necessary for the production of ammonia water from human urine in relation to a conventional WWTP with nitrogen removal (app. $4000 \mathrm{~m}^{3}$, without Nremoval app. $1000 \mathrm{~m}^{3}$ ).

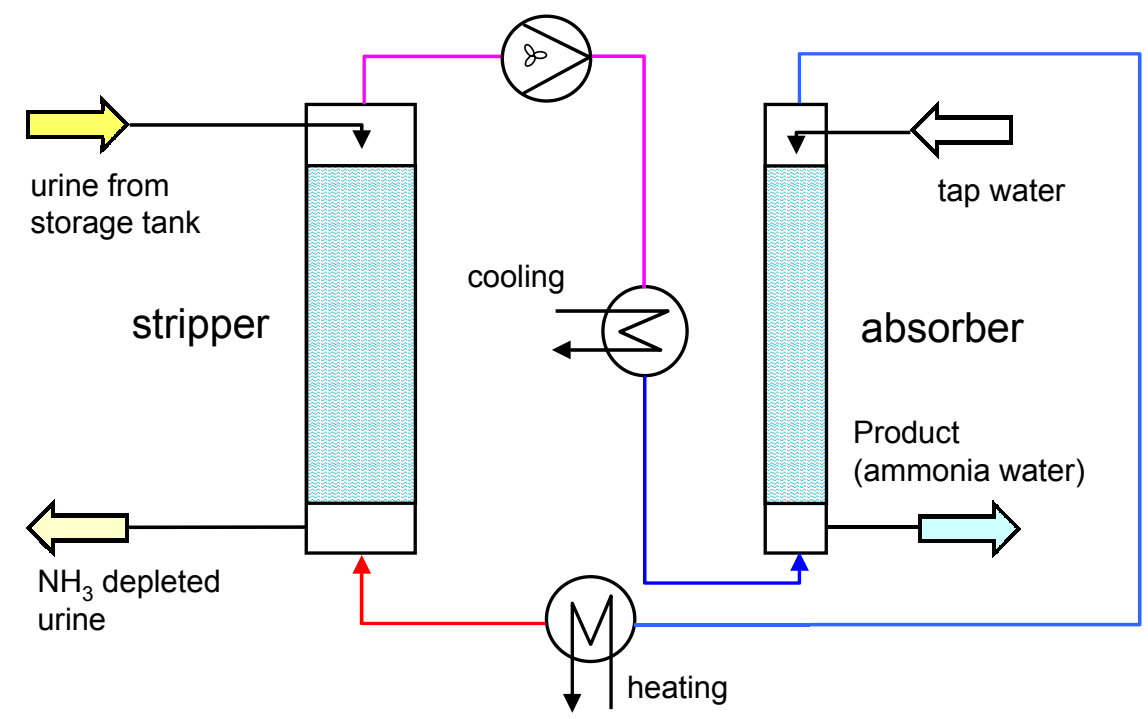

Figure 4. Process for the production of ammonia water from urine

Table 1. Dimensioning results for an ammonina stripper-absorber from human urine for 10,000 persons

\begin{tabular}{|l|l|l|}
\cline { 2 - 3 } \multicolumn{1}{c|}{} & Stripper Design & \\
\hline Packing depth & $10.5 \mathrm{~m}$ & Absorber Design \\
Column diameter & $0.82 \mathrm{~m}$ & $10.5 \mathrm{~m}$ \\
Temperature & $313.15 \mathrm{~K} \mathrm{resp} .40^{\circ} \mathrm{C}$ & $0.4 \mathrm{~m}$ \\
$293.15 \mathrm{~K}$ resp. $20{ }^{\circ} \mathrm{C}$ \\
Overall mass transfer coefficient KLA & $3.0 \mathrm{~h}^{-1}$ & $1.1 \mathrm{~h}^{-1}$ \\
Pressure & $0.4 \mathrm{bar}$ & $\mathrm{bar}$ \\
Gas flow & $237 \mathrm{~kg} / \mathrm{h}$ & $237 \mathrm{~kg} / \mathrm{h}$ \\
Liquid flow & $2,100 \mathrm{~kg} / \mathrm{h}$ & $180 \mathrm{~kg} / \mathrm{h}$ \\
Volume & $5.6 \mathrm{~m}^{3}$ & $1.3 \mathrm{~m}$ \\
\hline Assumptions: & $\mathrm{S}_{\mathrm{NH}}^{\text {in }}=5,000 \mathrm{~g} / \mathrm{m}^{3}$ & $10 \% \mathrm{w} / \mathrm{w}$ ammonia \\
Storage tank $50 \mathrm{~m}^{3}$ & $\mathrm{~S}_{\mathrm{NH}}^{\text {out }}=250 \mathrm{~g} / \mathrm{m}^{3}$ & solution \\
\hline
\end{tabular}

\section{CONCLUSION}

Urine and faeces separation is the first important step in order to try to produce valuable materials from those waste streams. For the case of the production of concentrated ammonia solutions from urine, it is of great importance that urine is pumped into the treatment process undiluted in order to have favourable conditions for ammonia stripping. This is just an example of the influence that the collecting method of municipal waste waters has on the possible ways to obtain valuable products from them. The production of IBDU is more complicated an has the great disadvantage, like the precipitation of struvite too, that there is a need of a relatively great amount of additional chemical. All these methods have in common that a additional treatment of the urine is necessary. 
From the results obtained it has been shown that the production of valuable products from yellow water is possible. In this way not only the wastewater volumes going to treatment plants are reduced, but also products that in some cases are very costly can be produced using relatively simple and easy to operate equipment.

\section{REFERENCES}

Braun, U. (2001) Methods and devices for separating and disposing of faeces and urine in urine separation toilets. Patent WO 01/25555 A1

Esrey,St.A., Gough,J., Rapaport,D., Sawyer,R., Simpson-Hébert,M., Vargas,J., and Winblad,U.e. (1998) Ecological Sanitation., Department for Natural Resources and the Environment, Sida, Stockholm, Sweden.

Galler, L. (2001) Trenntoilette. Patent DE 19958557 A1.

Gulyas, H. (2000) Gefrierkonzentration zur Wertstoffgewinnung aus Gelbwasser. Gulyas, H. and Otterpohl, R. In. 12. Kolloquium und Fortbildungskurs zur Abwasserwirtschaft. Regenwasserbewirtschaftung und Bauleitplanung, Eigenüberwachung, dezentrale Abwasserbehandlung, Geruchsbekämpfung, Provatisierung, 67-86. 2000. Hamburg, GEFU e.V. Hamburger Berichte zur Siedlungswasserwirtschaft.

Hellström,D. and Johansson,E. (1995) Swedish experiments with urine separating systems. Wasser \& Boden 51 (11), 26-29.

Jönsson,H., Vinnerås,B., Höglund,C., and Stenström,T.-A. (1999) Source separation of urine. Wasser \& Boden 51 (11), 21-25.

Lind,B.-B., Ban,Z., and Bydén,St. (2000) Nutrient recovery from human urine by struvite crystallization with ammonia adsorption onzeolite and wollastonite. BioresourceTechnology 73 169174.

Otterpohl,R. (2001) Design of highly efficient source control sanitation and practical experience. In: Lens,P., Zeeman,G., and Lettinga,G. (eds), pp. 165-180, IWA Publishing.

Strand, L. and Odén, L. (2000) Closing the Eco-cycles - nutrient recovery from human urine by struvite crystallization. http://www.northseanet.org/conference_doncaster/projects/project0002.html. 